\title{
NOVELTIES TO COMPOSITAE FAMILY IN RIO GRANDE DO SUL STATE FLORA ${ }^{1}$
}

\author{
LEONARDO PAZ DEBLE ${ }^{2}$ ANABELA SILVEIRA DE OLIVEIRA DEBLE ${ }^{3}$
}

\section{SUMMARY}

Twelve new records to Compositae from Rio Grande do Sul Flora are proposed: Soliva macrosperma Cabrera (Tribe Anthemidae); Baccharis coronata Giuliano, Baccharis flabellata Hook. \& Arn., Conyza pampeana (Parodi) Cabrera, Conyza serrana Cabrera, and Podocoma spegazzini Cabrera (Tribe Astereae); Micropsis ostenii Beauveard, Micropsis spathulata (Pers.) Cabrera, and Pseudognaphalium luteo-album (L.) Hilliard \& B. L. Burtt (Tribe Gnaphalieae); Trichocline humilis Less. (Tribe Mutisieae); Stenachaenium adenanthum (Sch. Bip. ex Krasch.) Krasch. (Tribe Plucheae); and Chrysolaena propinqua (Hieron.) H. Rob. var. canescens (Chodat) Dematt. (Tribe Vernonieae). The identity of Hysterionica nidorelloides DC. is defined, being Hysterionica montevidensis Baker its synonym. A superfluous combination under Viguiera santacatarinensis is included as new synonym. Isostigma riedelii (Baker) Chodat is excluded to Rio Grande do Sul Flora, and two new combinations are proposed: Calea paraguayensis (Kuntze) Deble and Vernonanthura nudiflora $\mathrm{f}$. albiflora (Matzenb.) Deble.

Key worlds: Asteraceae, checklist, new records, new synonyms, new combinations.

\section{RESUMO}

[Novidades para a família Compositae na Flora do Rio Grande do Sul].

Doze novas citações em Compositae para a Flora do Rio Grande do Sul são propostas: Soliva macrosperma Cabrera (Tribo Anthemidae); Baccharis coronata Giuliano, Baccharis flabellata Hook. \& Arn., Conyza pampeana (Parodi) Cabrera, Conyza serrana Cabrera e Podocoma spegazzini Cabrera (Tribo Astereae); Micropsis ostenii Beauveard, Micropsis spathulata (Pers.) Cabrera e Pseudognaphalium luteo-album (L.) Hilliard \& B. L. Burtt (Tribo Gnaphalieae); Trichocline humilis Less. (Tribo Mutisieae); Stenachaenium adenanthum (Sch. Bip. ex Krasch.) Krasch. (Tribo Plucheae); e Chrysolaena propinqua (Hieron.) H. Rob. var. canescens (Chodat) Dematt. (Tribo Vernonieae). A identidade de Hysterionica nidorelloides DC. é definida, e Hysterionica montevidensis Baker reconhecida na sinonímia desta espécie. Uma combinação supérflua em Viguiera santacatarinensis é incluída como novo sinônimo. Isostigma riedelii (Baker) Chodat é excluída da flora sul-rio-grandense e duas novas combinações são propostas: Calea paraguayensis (Kuntze) Deble e Vernonanthura nudiflora f. albiflora (Matzenb.) Deble.

Palavras chave: Asteraceae, checklist, novas citações, novas sinonímias, novas combinações.

\section{INTRODUCTION}

During the elaboration of a survey of the Compositae from Rio Grande do Sul state (Brazil), including the revision of Herbarium material (CNPO, CTES, FLOR, HAS, HBR, HDCF, ICN, LP, MBM, MVM, PACA, R, RB, SI, SMDB, UNILASALLE), new collections and analyzes of types, led us to recognize some novelties that are subsequently presented.

\footnotetext{
1 Recebido em 20-04-2011 e aceito para publicação em 12-06-2011.

2 Biólogo, Dr. Prof. da Universidade da Região da Campanha (URCAMP - Bagé, RS).

3 Bióloga, Dra. Prof ${ }^{a}$. da Universidade da Região da Campanha (URCAMP - Dom Pedrito, RS).
}

\section{RESULTS}

\section{Tribe Anthemidae Cass.}

1. Soliva macrosperma Cabrera, Notas Mus. La Plata Bot. 14 (70): 137. 1949.

The species is easy determined by bigger and sessile capitula, as well as oblong, entire and undulate wings of cypselas. Soliva macrocephala is presently cited from Brazil, where it was found in the called "Campanha Gaúcha".

Iconography: Cabrera, 1974: 427(fig. 251, h-n).

Material examined: BRAZIL. Rio Grande do Sul, Alegrete, "Rincão do 28, campo hidrófilo, na sede da Marona", 29- IX-2004, L. P. Deble \& A. S. de Oliveira-Deble 4009 (CNPO). Bagé, "estrada para Aceguá, em campo hidrófilo, en- 
tre gramíneas", X-2005, L. P. Deble \& A. S. de Oliveira-Deble 4878 (HDCF).

\section{Tribe Astereae Cass.}

Astereae includes above 140 species in Rio Grande do Sul, and comprises the highest center of diversity to tribe in the country. Two new records in Baccharis are proposed, two species of Conyza are included in Brazilian flora, Podocoma spegazzini Cabrera was found by writers in Rio Grande do Sul, and Hysterionica nidorelloides DC. is defined as the old name to well known Hysterionica montevidensis Baker, as well.

1. Baccharis coronata Giuliano, Novon 16(4): 490. 2006.

The species was described as endemic of Santa Catarina state, its occurrence is extended to Rio Grande do Sul, Cambará do Sul and São José dos Ausentes municipalities.

Iconography: Giuliano, 2006: 491 (fig. 1, a-g).

Material examined: BRAZIL. Rio Grande do Sul, São José dos Ausentes, "cânion do Monte Negro", $1250 \mathrm{~m}, 16-\mathrm{XI}-2006$, L. P. Deble \& A. S. de Oliveira-Deble 6712 (MBM).

2. Baccharis flabellata Hook. \& Arn. J. Bot (Hooker) 3: 28. 1841.

The species occurs in southeast Paraguay and center-north of Argentina (Cordoba, La Rioja, Entre Rios, Santiago del Estero, San Juan, San Luis provinces). A single collection made by Hagelund was first determined by the second author as Baccharis petraea Heering (Oliveira \& Marchiori, 2006), the revision of types and additional collections in northeast of Argentina evidenced that the material correspond to Baccharis flabellata, furthermore $B$. petraea is excluded to Rio Grande do Sul Flora.

Iconography: Freire \& Molina, 2009: 200 (fig. 73, a-e).

Material examined: BRAZIL. Rio Grande do Sul. Giruá, Granja Sodol, masc., 3-VIII-1963, K. Hagelund s.n. (ICN 106367).

3. Conyza pampeana (Parodi) Cabrera, Manual de la Flora de los alrededores de Buenos Aires: 481. 1953. Erigeron pampeanus Parodi,
Rev. Fac. Agron. Veterin. 7: 252. 1930.

Conyza pampeana is characterized by smaller habit and entire, linear, at base decurrent leaves. The species grows near bogs and wet grasslands in Argentina, Uruguay and in south of Rio Grande do Sul, Rosário do Sul, Alegrete and Cacequi municipalities.

Iconography: Cabrera, 1974: 220 (fig. 115, t-z).

Material examined: BRAZIL. Rio Grande do Sul. Alegrete, "em campo hidrófilo no norte da Serra do Caverá", 26- II-2006, L. P. Deble \& A. S. de Oliveira-Deble 6976 (CTES). Cacequi, "Estrada do umbu, em campo hidrófilo, várzea de arroz, erva verde claro", 29- XII-2006, L. P. Deble \& A. S. de Oliveira-Deble 7455 (CTES)

4. Conyza serrana Cabrera, Flora Prov. Buenos Aires 6: 87. 1963.

This species was originally described to mountains of Buenos Aires province, collections made by writers in Quaraí municipality, extend its occurrence also from Brazil.

Iconography: Cabrera, 1978: 186 (fig. 81bis, a-f).

Material examined: BRAZIL. Rio Grande do Sul. Quaraí, Palmar do Coatepe, em campo rupestre, 5-III-2011, L. P. Deble \& A. S. de Oliveira-Deble 12916 (CTES).

5. Hysterionica nidorelloides (DC.) Baker, Fl. Bras. (Martius): 6 (3): 12. 1882. Neja nidorelloides DC. Prodr. 5: 325. 1836.

= Diplopappus villosus Hook. \& Arn., Comp. Bot. Mag. 2: 48. 1836. Hysterionica villosa (Hook. \& Arn.) Cabrera, Not. Mus. La Plata, 11: 350. 1946. syn. nov.

= Hysterionica montevidensis Baker, Fl. Bras. (Martius): 6(3): 13. 1882. syn. nov.

The collection Sellow s.n. [HIB 1048] corresponds at type of Neja nidorelloides, and also the first-one material cited by Baker (1882) above Hysterionica nidorelloides.

Iconography: Cabrera, 1974: 229 (fig. 121, a-g [under Hysterionica villosa]).

6. Podocoma spegazzini Cabrera Not. Prelim. Mus. La Plata 1: 327. 1931.

Podocoma spegazzini was originally described to Uruguay. Recently, Podocoma 
asperrima Dusén ex Malme, with occurrence in Paraná State, was within their submerged (Sancho et al., 2010). Podocoma spegazzini can be easy determined by rigid, clothe hirsute trichomes leaves. Collections made by writers in west, Maçambará municipality add the species from Rio Grande do Sul Flora.

Iconography: Malme, 1933: 127 (tab. 3).

Material examined: BRAZIL. Rio Grande do Sul, Maçambará, dois cerros, entre rochas, próximo a palmar de Butia paraguayensis, II-2007, $L$. P. Deble \& A. S. de Oliveira-Deble 7192 (CTES).

\section{Tribe Coreopsideae B.L.Turner \& A.M.Powell}

In the recent revision of the genus Isostigma, Peter (2009) recognizes the Rio Grande do Sul as place of collection at type of Isostigma riedelii (Chodat) Baker (as I. simplicifolium Less. var. riedelii (Baker) Guad. Peter). The collection was made by Riedel, but he never gathered specimens in Rio Grande do Sul, some well, during the revision of Herbaria material and trips, this species was not found, being Isostigma riedelii excluded to Rio Grande do Sul Flora.

\section{Tribe Gnaphalieae Cass. ex Lecoq \& Juill.}

The tribe Gnaphalieae is well defined in Rio Grande do Sul, being represented by 45 species distributed in 8 genera. Collections made by writers in north of Bagé municipality include to Brazilian flora two species of Micropsis. Additionally, Pseudognaphalium luteo-album is definitively found in the country.

1. Micropsis ostenii Beauverd, Bull. Soc. Bot. Genéve, ser. 2, 5: 226. 1913.

Micropsis ostenii is easy characterized by capitula solitary in axils of distal leafs. The species grows in wet grasslands.

Iconography: Cabrera, 1974: 288 (fig. 162, a-i).

Material examined: BRAZIL. Rio Grande do Sul, Bagé, Casa de Pedra, “em campo hidrófi- 1o", 24-IX-2009, L. P. Deble \& A. S. de Oliveira-Deble 10533 (CTES).

2. Micropsis spathulata (Pers.) Cabrera, Not. Mus. La Plata 9: 254. 1944. Evax spathulata Pers. Syn. P1. 2: 422.1807.

Micropsis spathulata was found by authors in a smaller area between Bagé and Lavras do Sul cities, growing in stony and wet grasslands frequently associated with Sellaginela selloi and two Compositae species: Panphalea heterophyla and Perezia multiflora ssp. sonchifolia.

Iconography: Cabrera, 1974: 289 (fig. 163, a-i).

Material examined: BRAZIL. Rio Grande do Sul, Bagé, Rincão do Inferno, campo e rochas, úmido, 4-XI-2004, L. P. Deble \& A. S. de Oliveira-Deble 2370 (CTES).

3. Pseudognaphalium luteo-album (L.) Hilliard \& B. L. Burtt, Bot. Journ. of the Linn. Soc. 82: 206. 1981. Figure 1.

In the synopses of the genus Pseudognaphalium from Brazil, Deble \& Marchiori (2006) treated this species as doubtful to country, because only a classical collection gathered by Sellow was examined. Recently, the writers found populations growing in grasslands in Aceguá municipality, in the border with Uruguay.

Material examined: BRAZIL. Rio Grande do Sul, "prov. Rio Grande", Sellow s.n. [HIB = 992] (R). Aceguá, "em campo, próxima a serra de Aceguá, norte da cidade", 7-VIII-2009, L. P. Deble \& A. S. de Oliveira-Deble 11841 (CTES).

\section{V - Tribe Heliantheae Cass.}

1. Viguiera santacatarinensis (H. Rob. \& A. J. Moore) A. A. Sáenz, Darwiniana 45 (2): 236. 2007. Rhysolepis santacatarinensis H. Rob. \& A.J. Moore, Proc. Biol. Soc. Wash. 117(3): 441. 2004. Viguiera santacatarinensis (H. Rob. \& A. J. Moore) M. Magenta \& Mondin, Rodriguesia 61 (1): 10. 2010. comb. superfl.

We included the combination proposed by Magenta \& Mondin (Magenta et al., 2010) as superfluous. 


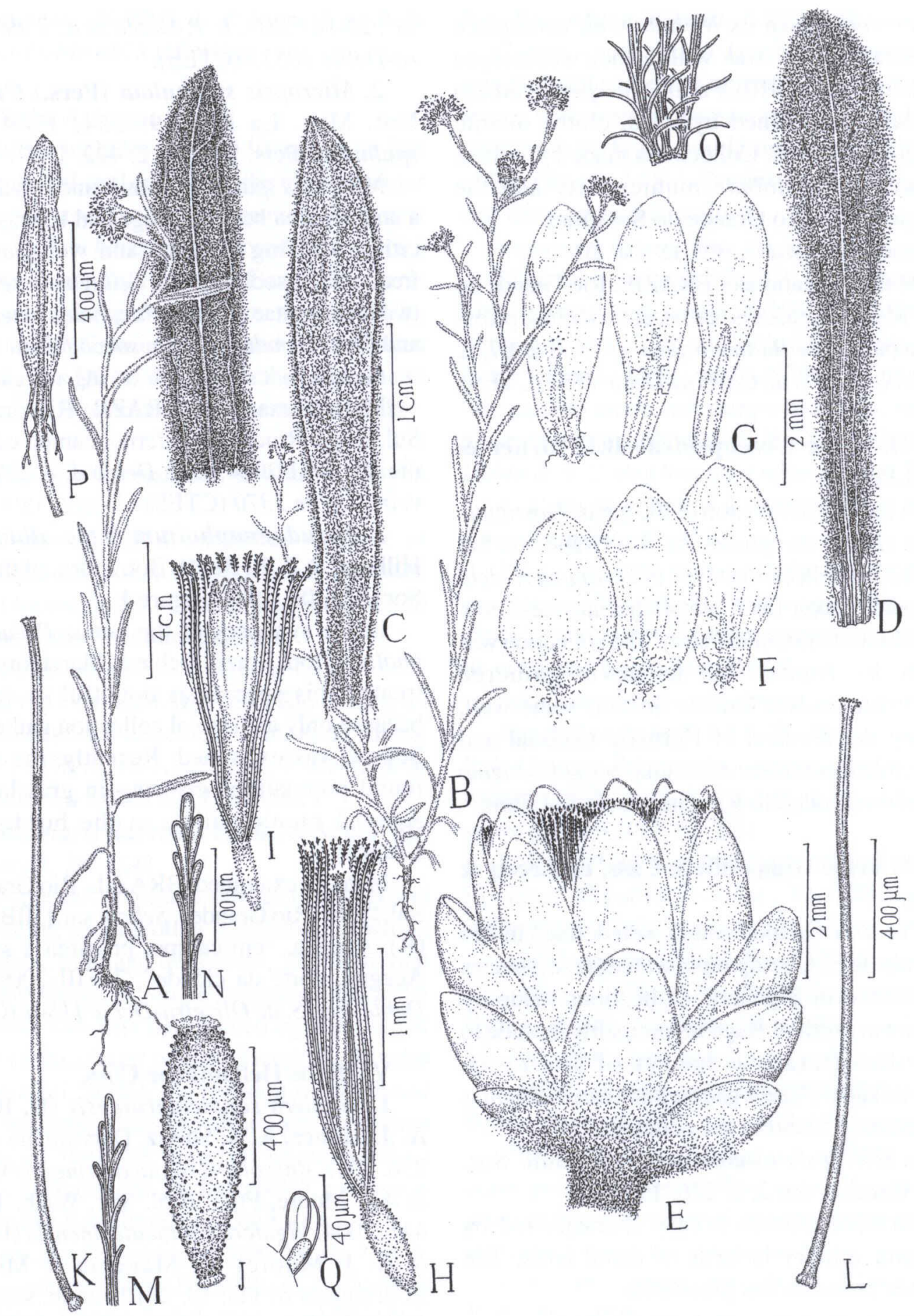

FIGURE 1 - Pseudognaphalium luteo-album. A: Plant. B: Plant. C: leaf. D: basal leaf adaxial surface. E: Capitulum. F: Outermost involucral bracts. G: Innermost involucral bracts. H: Female flower. I. Perfect flower. J: Cypsela. K. Style of female flower. L: Style of perfect flower. M: Pappus apex of female flower. N: Pappus apex of perfect flower. O: Pappus base of female flower. P: Anther. Q: twin-trichome from cypsela (A, C-Q, Sellow s.n. [= HIB 992]; B, Deble \& Oliveira-Deble 11841). Scale bar near N from N, M and O. 


\section{VI - Tribe Mutisieae Cass.}

\section{Trichocline humilis Less.}

Comments. In recent trips from southwest, collections of Trichocline humilis were made by authors in Barra do Quaraí. the species was found growing in grasslands.

Material examined: BRAZIL. Rio Grande do Sul, Barra do Quaraí, Parque de Inhanduvá, no campo, 14-III-2011, L. P. Deble \& A. S. de Oliveira-Deble 13089 (CTES).

Iconography: Cabrera, 1974: 480 (fig. 284, a-k).

\section{VII - Tribe Neurolaeneae Rydb.}

The tribe comprises two genera (Calea, Enydra), with nine species in Rio Grande do Sul, being Calea kristiniae Prusky endemic in Rio Grande do Sul and north Uruguay; a new combination into Calea is herein proposed to species that grows also in Paraguay and probably northeast Argentina.

1. Calea paraguayensis (Kuntze) Deble, comb. nov. Bas. Tridax paraguayensis Kuntze, Rev. Gen. 3 (2): 182. 1898. Type: Paraguay. "süd-paraguay". Figure 2.

Comments. Calea paraguayensis is closely related with Calea uniflora Less. var. uniflora, and the material collected in Rio Grande do Sul was a long time within theirs included, but can be segregated by following features: ray flowers cream-white (vs. absent or yellow), veins pink to purple, thin membranaceous ligulae (vs. veins yellow to orange, membranaceous ligulae), innermost involucral bracts at apex acute (vs. obtuse to rounded), lobes of perfect flowers 1.5 $\mathrm{mm}$ long (vs. 0.7-1.2 mm), additionally the species display bigger habit and capitulae.

Distribution and Ecology: Calea paraguayensis occurs in southernmost portion of Paraguay and west of Rio Grande do Sul state, growing in sandy grasslands and stony. Material with flowers and fruits was gathered during October-April.

Material examined: Alegrete, Cerro do Tigre, Santo Antão, na encosta do cerro, XII-2001, A. M. Girardi-Deiro et al. s.n. (CNPO). São
Francisco de Assis, Cerro, em solo franco arenoso, flores branco-rosadas, II-2007, L. P. Deble \& A. S. de Oliveira Deble 7093 (CTES).

\section{VIII - Tribe Plucheae Anderb.}

The tribe comprises 17 species distributed into four genera in Rio Grande do Sul, a species of Stenachaenium is cited to Rio Grande do Sul Flora.

1. Stenachaenium adenanthum (Sch.-Bip. ex Krasch.) Krasch. Not. Syst. Herb. Hort. Petrop. 4: 49. 1923. Figure 3.

Stenachaenium adenanthum grows in grasslands near to border with Santa Catarina. The species is endemic to Brazil, being also represented in São Paulo, Paraná and Santa Catarina states. In the taxonomic study of the genus from Rio Grande do Sul (Marodin \& Ritter, 1997) its material was treated under Stenachaenium campestre Baker, a close related species. Its can be segregated by following features: obovate densely clothed by yellowish trichomes leaves (vs. oblanceolate, sparsely clothed by trichomes), and smaller densely glandular cypselas (3-4 mm long vs. 6-7 mm long). The species is poorly known, and during the revision of literature no iconography references was found. Stenachaenium adenanthum is illustrated by first time herein.

Material examined: BRAZIL. Rio Grande do Sul, Bom Jesus, "estrada Santo Inácio-São Joaquim", 12-XII-1995, M. R. Ritter 881 (ICN). São José dos Ausentes, distrito de Silveira, "próximo ao rio Pelotas" 9-XII-1994, M. R. Ritter \& S. M. Marodin 809 (ICN); idem, "próximo ao rio do Marco", 9-XII-1994, M. R. Ritter \& S. M. Marodin 813 (ICN).

\section{IX - Tribe Vernonieae Cass.}

Vernonieae is well represented in Rio Grande do Sul, and include above 45 species, 3 varieties and one form distributed in 10 genera. Based in the recent review of the genus Chrysolaena (Dematteis, 2009) a new record is assigned to Rio Grande do Sul. Furthermore, with the transference of Vernonia nudiflora 


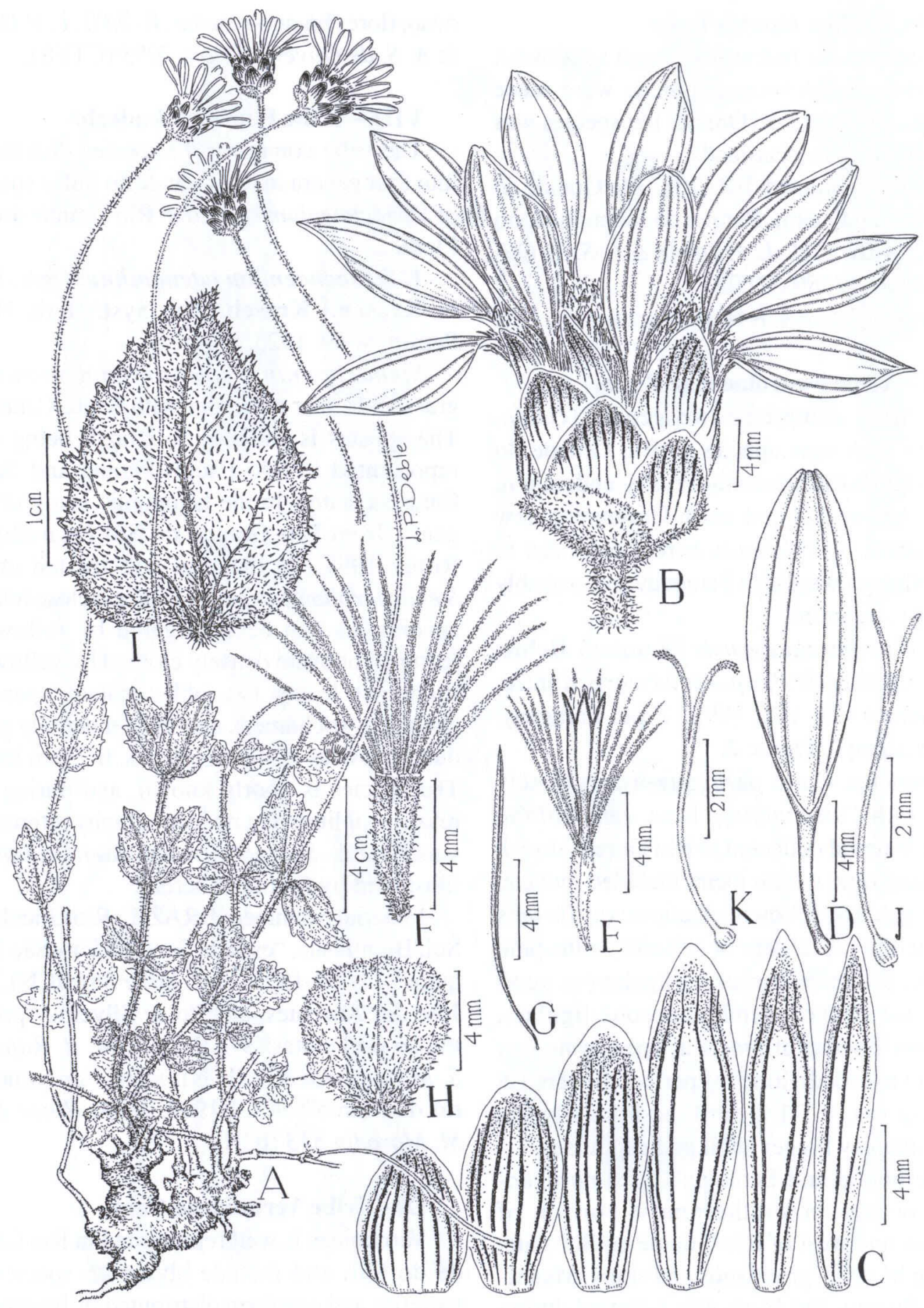

FIGURE 2 - Calea paraguayensis. A: Plant. B: Capitulum. C: Involucral bracts. D: Corolla of ray flower. E: Disk flower. F: Cypsela and pappus. G: Paleae. H: Leafy bract. I: Leaf. J: Style of ray flower. K: Style of disk flower (A-I, Deble \& Oliveira-Deble 7093). 


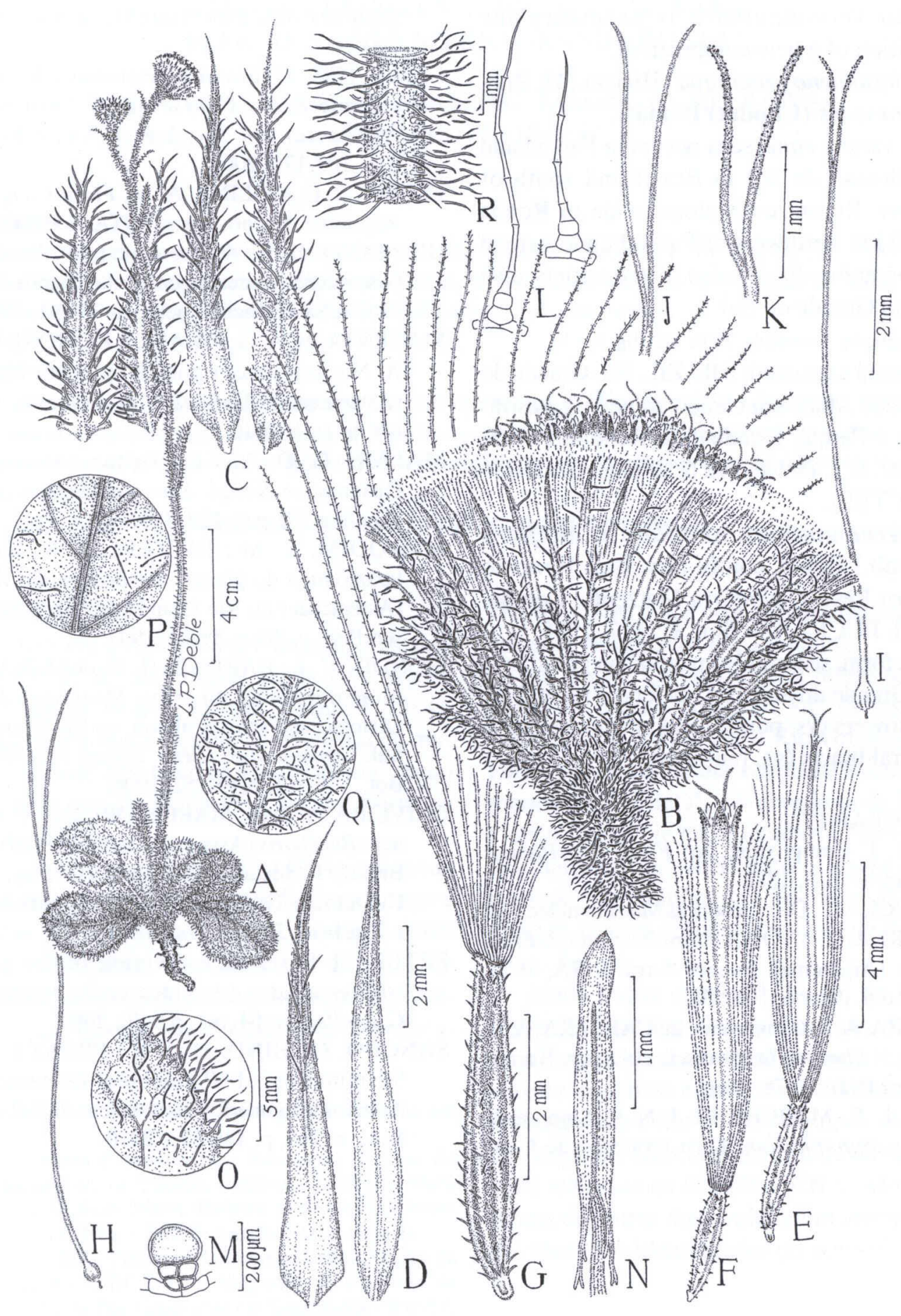

FIGURE 3 - Stenachaenium adenanthum. A: Plant. B: Capitulum. C: Outermost involucral bracts. D: Innermost involucral bracts. E: Female flower. F. Perfect flower. G: Cypsela and pappus. H. Style of female flower. I: Style of perfect flower. J: Style apex of female flower. K: Style apex of perfect flower. L: trichomes from leaf. M: glandular trichome from leaf. N: Anther. O-Q: Leaf detail. O-P: Adaxial surface. Q: Abaxial surface. R: Stem. (A-R, Ritter \& Marodin 809). Scale bar near $\mathrm{K}$ from $\mathrm{K}$, J and L; Scale bar near O from O, P and Q. 
Less. to Vernonanthura is necessary the proposition of a new combination.

1. Chysolaena propinqua (Hieron.) H. Rob. var. canescens (Chodat) Dematt.

The variety canescens occurs in Paraná and Mato Grosso do Sul in Brazil and south of Paraguay. Recent collections made in Ronda Alta, $60 \mathrm{~km}$ northwest of Passo Fundo extend the geographic distribution of the variety also from Rio Grande do Sul.

Iconography: Dematteis, 2009: 122 (fig. 9, a-b).

Material examined: BRAZIL. Rio Grande do Sul. Ronda Alta, "em campo arenoso, na estrada para o Parque Estadual de Rondinha", 12XII-2009, L. P. Deble \& A. S. de Oliveira-Deble 11791(CTES).

2. Vernonanthura nudiflora f. albiflora (Matzenb.) Deble, comb. nov. Bas. Vernonia nudiflora Less. f. albiflora Matzenb., Comun. Mus. Ci. PUCRS, sér. Bot. 37: 117. 1985.

This form, seemingly endemic on grasslands in Rio Grande do Sul state, differs of typical by white flowers (vs. purple) and at apex greenish involucral bracts (vs. purplish).

\section{BIBLIOGRAPHY}

BAKER, J. Compositae. In: Flora brasiliensis (Martius) 6, 3, 1882.

CABRERA, A. L. Dicotiledoneas Metaclamideas. In: BURKART, A. (Org.). Flora Ilustrada de Entre Rios (Argentina). Buenos Aires: INTA, 1974. Tomo 6, Parte 6. 106-538.

CABRERA, A. L. Compositae. In: CABRERA, A. L. (Org.). Flora de la Provincia de Jujuy. Buenos Aires: INTA, 1978. 726p.

DEBLE, L. P.; MARCHIORI, J. N. C. Sinopse de Pseudognaphalium Kirp (Asteraceae-Gna- phalieae). Balduinia, Santa Maria, n.9, p.13-16. 2006.

DEMATTEIS, M. Revisión taxonômica del género sudamericano Chrysolaena (Vernonieae, Asteraceae). Bol. Soc. Argent. Bot., v. 44, n. 12, p. 103-170. 2009.

FREIRE, S. E; MOLINA, A. M. Flora ChaqueñaArgentina. Buenos Aires: INTA, 2009. 640p.

GIULIANO, D. A. A new species of Baccharis (Asteraceae-Astereae) from Santa Catarina, Brazil. Novon, San Francisco, v.16, p.490-491, 2006.

MAGENTA, M. A. G.; PIRANI, J. R.; MONDIN, C. A. Novos táxones e combinações em Viguiera (Asteraceae-Heliantheae). Rodriguesia, v. 61, n.1, p. 1-11, 2010.

MALME, G. O. A. Compositae paranaenses Dusenianae Kongl. Svenska Vetensk. Acad. Handl, n. 12, p. 1-122, 1933.

MARODIM, S. M.; RITTER, M. R. Estudo taxonômico do gênero Stenachaenium Benth. (Asteraceae) no Rio Grande do Sul. Iheringia, ser. Bot., n. 48, p. 59-84, 1997.

MONDIN, C. A.; BAPTISTA, L. R. de M. Relações biogeográficas da tribo Mutisieae Cass. (Asteraceae), sensu Cabrera, no Rio Grande do Sul. Comum. Mus. Ciênc. Tecnol. PUCRS, ser. Bot., v. 2, n.1, p.49-152, 1996.

OLIVEIRA, A. S. de; MARCHIORI, J. N. C. O gênero Baccharis (Astereae-Asteraceae) no sul do Brasil, 1. Seção Cylindricae Heering, série Cylindricae Giuliano. Balduinia, Santa Maria, n.7, p.1-36, 2006.

PETER, G. Systematic revision of the genus Isostigma Less. (Asteraceae, Coreopsideae). Candollea, v. 64, n.1, p.5-30, 2009.

SANCHO, G.; HIND, D. J. N.; PRUSKY, J. F. Systematics of Podocoma (Asteraceae: Astereae): a generic reassessment. Bot. J. Linn. Soc., n. 163, p. 486-513, 2010. 